\section{Marko Penčić \\ Research Assistan University of Novi Sad Faculty of Technical Sciences \\ Maja Čavić \\ Assistant Professor University of Novi Sad Faculty of Technical Sciences \\ Branislav Borovac \\ Professor University of Novi Sad Faculty of Technical Sciences}

\title{
Development of the Low Backlash Planetary Gearbox for Humanoid Robots
}

The low backlash planetary gearbox as a substitute for a harmonic drive in humanoid robotics, is presented in this paper. After analysis of the contemporary designs of the low backlash coaxial toothed gearboxes, a concept of planetary gearbox with taper gears has been chosen. A synthesis of a planetary mechanism which satisfies the prescribed kinematic-dynamic requirements as well as the design limitations has been performed. Based on the obtained results, parameters necessary for the gearbox design have been defined. The proposed solution has been analysed from various points of view. Analysis results show that the proposed solution has low backlash ( $<4$ arcmin), high coefficient of efficiency (about 97\%), four times higher load capacity and five times lower price in comparison with the currently available corresponding harmonic drives. Overall dimensions are nearly the same, while the mass of the planetary gearbox is $10 \%$ larger than mass of the corresponding harmonic drive.

Keywords: low backlash, planetary gearbox, harmonic drive, humanoid robot

\section{INTRODUCTION}

Mechanical gearboxes used in humanoid robotics have to satisfy a lot of requirements: functionality and reliability, high positioning accuracy and repeatability, high efficiency, compact design, low mass and moments of inertia, low vibrations, low noise etc.

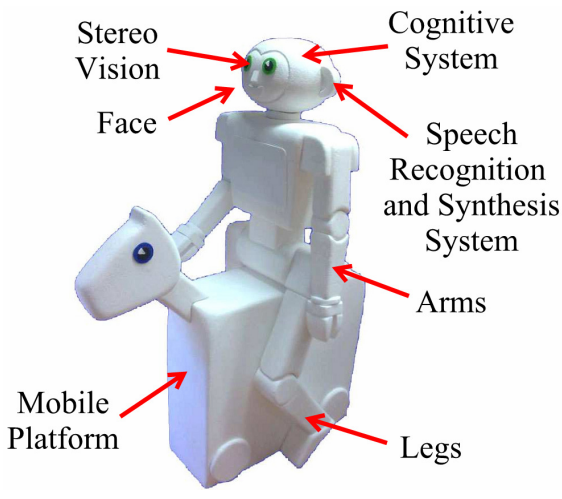

Figure 1. Robot MARKO - concept

The most commonly used solution for a gearbox in robotics is a harmonic gearbox, known as harmonic drive. In addition to simple design, small mass and high transmission ratio, they have extremely small backlash (less than one angular minute). Thanks to that, they ensure precise positioning thus obtaining high accuracy and repeatability of the movement, which is of great importance for the motion control. One serious draw-

Received: February 2015, Accepted: September 2015 Correspondence to: Marko Penčić

Faculty of Technical Sciences,

Trg Dositeja Obradovića 6, 21000 Novi Sad, Serbia

E-mail: mpencic@uns.ac.rs

doi:10.5937/fmet1701122P

(C) Faculty of Mechanical Engineering, Belgrade. All rights reserved back of the harmonic drives is their significantly high price which, in many cases, limits their application.

The development of a low backlash planetary gearbox for humanoid robots as a substitute for the harmonic drive is presented in this paper. The research is conducted as part of a national project whose goal is to design a mobile humanoid robot "MARKO" as an assisting apparatus for the rehabilitation of children with cerebral palsy [1]. Conceptual design of this robot is shown on Fig. 1.

The robot's arm was inspired by the biomechanical characteristics of the human arm and it has seven degrees of freedom (Fig. 2). Brushless Dunker DC motors and Firgelli actuators were used for rotational and linear joint actuation, respectively. The design solution is adapted to incorporate previously mentioned drive units [2].

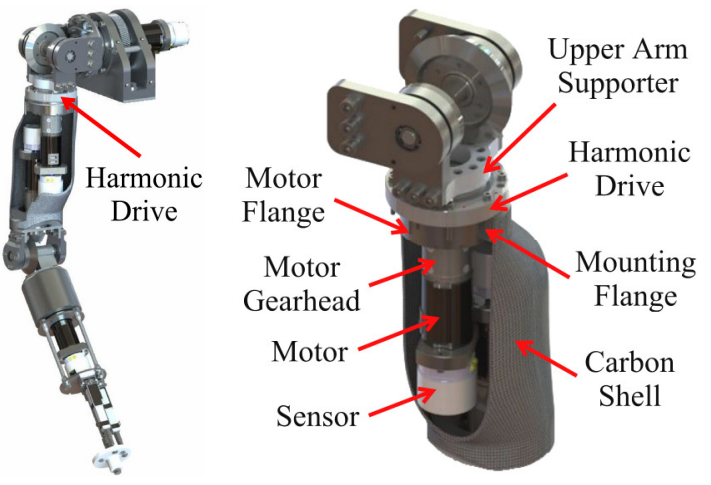

Figure 2. Design of robot's arm and robot's upper arm

The robot's upper arm, with a shell made of carbon fibres, is shown on Fig. 3. Inside the carbon shell two motors are mounted - one for rotation of the upper arm and the other for flexion of the lower arm. The mechanical gearbox used for the upper arm rotation is a harmonic drive (Fig. 3) [3]. 
Flexspline of the harmonic drive is attached to the upper arm support. The motor, attached to the motor flange, has its shaft connected to the wave generator. The motor flange is attached to the circular spline and it rotates with it. The mounting flange is attached to the circular spline. The carbon shell is attached to the mounting flange.

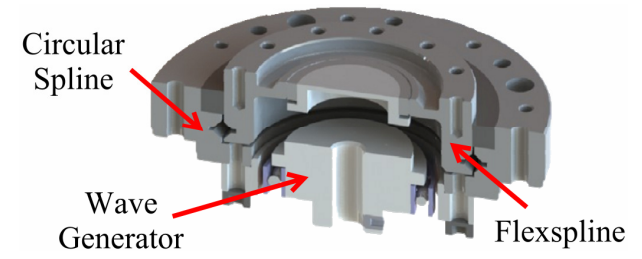

Figure 3. Harmonic drive CPU-14A-100-M

Torque is transmitted from the motor via the motor gearhead to the wave generator from which it passes to the circular spline thus starting rotation of the upper arm and motor. Both, the motor and the upper arm rotate in the same direction. Torque required for rotation of the upper arm equals $T=4.4 \mathrm{Nm}$ and the required number of revolutions of the upper arm is $n=15 \mathrm{rpm}$.

\subsection{Low backlash mechanical transmissions gears}

Backlash represents the rotation angle of the output shaft, if the input shaft is stationary and it is measured in angular minutes (arcmin). If the value of this angle is less then 10 arcmin, the gearbox is said to have low backlash [4].

Many aspects influence the total value of the backlash of the toothed gearboxes, the most significant ones being the backlash between the gear teeth and the backlash in the ball bearings. By choosing an adequate type of bearing, it is possible to eliminate their influence on the total backlash of the toothed gearbox.

In the case of universal toothed gearboxes [5], value of the backlash is not very important, but it has great importance for low backlash gearboxes - low backlash between meshed gears is necessary for the required positioning accuracy.

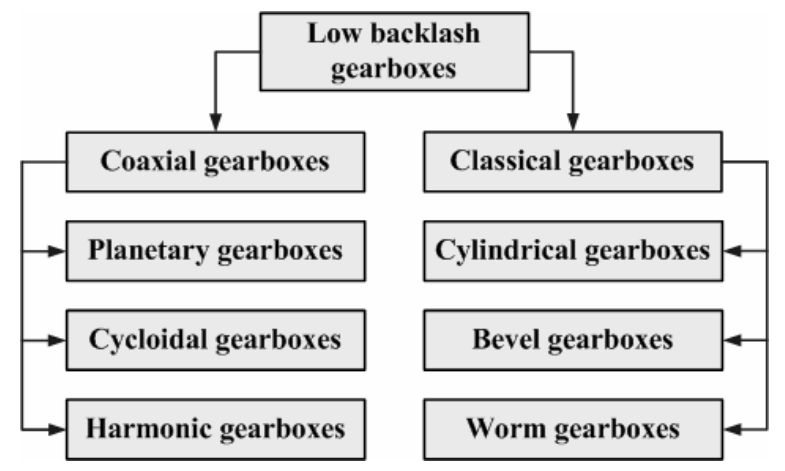

Figure 4. General classification of low backlash gearboxes

The purpose of this paper is a reconstruction of the robot's existing upper arm drive. The new gearbox must be coaxial, compact and with little to no backlash. Classic low backlash gearboxes do not meet these requirements, so low backlash gearboxes with the coaxiality trait must be taken under consideration (Fig. 4.).

Low backlash in toothed gearboxes is achieved in the following ways:
- With precise manufacturing and selection (low backlash is easily obtained, but short-lived in the case of the transmission of high loads, due to the wear of gear tooth flanks thus increasing the backlash; this way of achieving low backlash is used for motion transmission, for intermittent drives and when a great number of gears in meshed),

- With preload (low backlash is easily maintained, but the losses and wear of gear tooth flanks is much higher; this way of achieving low backlash is used only in motion transmissions - measuring instruments and short-term drives),

- With radial repositioning (low backlash is easily obtained and maintained, but impossible to achieve in planetary gearboxes which are the most commonly used ones today, it is a sustainable only in classic toothed gearboxes) and

- With axial repositioning (by bringing closer the slightly conical cylindrical gears - taper gears, low backlash is easily obtained and maintained, while the manufacture is more complex).

Low backlash planetary gearboxes with spur gears are the ones most commonly used, since they are very compact, simple and cheap, as well as having a small arc backlash. The Neugart company manufactures them with a transmission ration of 3...10 (single-stage), an arc backlash $<1$ arcmin (micro-accuracy), $<3$ arcmin (increased accuracy) and $<6$ arcmin (standard accuracy), as well as the coefficient of efficiency of $97 . . .98 \%$ [6]. Low backlash is achieved with precise manufacturing and selection.

Low backlash planetary gearboxes with helical gears are used fairly often as well. They are simple, but more expensive than the previously mentioned and with an even lower backlash due to the gears' higher rigidity. The Neugart company manufactures them with a transmission ratio of 4 ...10 (single-stage), an arc backlash $<1$ arcmin (micro-accuracy) and $<3$ arcmin (standard accuracy), as well as an coefficient of efficiency of $98 \%$. Low backash is achieved with precise manufactu-ring and selection.

Classic low backlash gearboxes are usually made using taper gears, which have a taper angle of about 3 degrees, and the desired low backlash is obtained through axial repositioning of the gears. A typical example is the two-stage low backlash gearbox, made by the Ondrives company, with an arc backlash $<8$ arcmin [7].

Cycloid gearboxes are used often as well, despite their relatively high price, because of their very low backlash, the longevity of that low backlash (a large number of teeth in meshed), and the ability to transmit high torque as well as the high transmission ratios. They are manufactured with one, two or three cam shafts. Sumitomo manufactures them with a transmission ratio of $29 . .179$ (single-stage), an arc backlash $<0,5$ arcmin (micro-accuracy) and $<1$ arcmin (standard accuracy) [8].

Harmonic gearboxes, known as Harmonic Drive gears, have significant application in robotics because of its compact construction, high transmission ratios and highly accurate positioning. Due to the high contact ratio, the load on the individual gear teeth is relatively 
small, making the wear on them low as well, and this allows harmonic drives to maintain their low backlash for a long time. The accuracy of harmonic drives used in robotics varies from $1( \pm 0.5)$ to $3( \pm 0.5)$ arcmin. The accuracy increases with the transmission ratio of the gearbox.

In [10], the development of a planetary gearbox with spur gears for humanoid robots with an arc backlash value estimated below 5 arcmin is shown. Low backlash is achieved with precise manufacturing and selection.

Planetary gearbox with taper gears, as the design solution for the backlash elimination, could not be found in the available literature. With this type of gears, low backlash is obtained and maintained in a very simple manner, while the machining process, which is described in [11], [12], can be easily performed on standard gear manufacturing machinery. In the following chapters, the concept of a low backlash planetary gearbox with taper gears is considered.

\section{DESIGN TASK}

Planetary gearboxes are convenient for humanoid robots because of their high load carrying capacity, high coefficient of efficiency, wide interval of transmission ratio, compact design, rather small dimensions for an acceptable mass. The input and output shafts of the planetary gearbox are coaxial - same as in a harmonic drive.

Harmonic gearbox have smaller backlash but a very high price, while a planetary gearbox have a higher load carrying capacity, a better coefficient of efficiency and a significantly lower price, all for the same overall dimensions. Because of this, it would be reasonable to use a planetary gearbox instead of a harmonic gearbox.

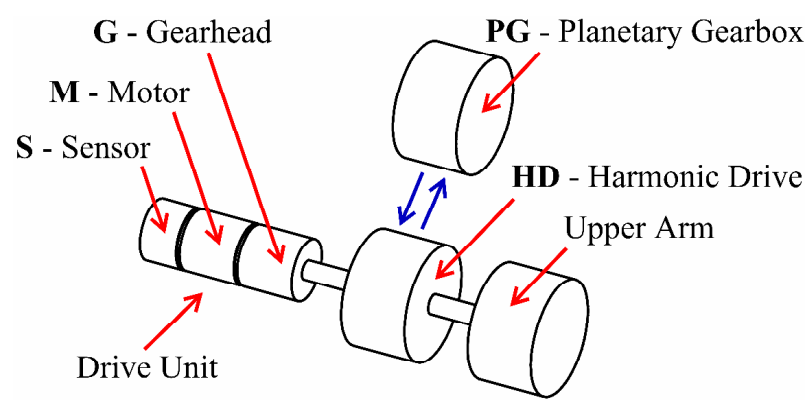

Figure 5. Drive system of the upper arm

The current solution of the drive for the robot's upper arm rotation is presented on Fig. 5. The motor (M), through the gearhead $(\mathrm{G})$ and the harmonic drive (HD), actuates the upper arm. The drive unit consists of the sensor $(\mathrm{S})$, motor $(\mathrm{M})$ and gearhead $(\mathrm{G})$. Because of the function requests (upper arm rotation), kinematic and dynamic requests (velocity and torque) and design requests (simple assembly and low backlash), two gearboxes are used: a gearhead $(\mathrm{G})$ and a harmonic drive (HD). Technical characteristics of harmonic drive CPU14A-100-M [3], used in the current design solution, are:

- torque: $T=7,8 \ldots 11 \mathrm{Nm}$, depending on the work regime,

- efficiency: $\eta=65 \%$ for input number of revolutions: $n=15 \mathrm{rpm}$,

- transmission ratio: $i=100$,
- weight: $0,54 \mathrm{~kg}$ and

- dimension: $\varnothing 78 \times 32 \mathrm{~mm}$.

Motors (M) which are going to be used in the previously mentioned humanoid robot design have different power and torque characteristics. Output torque of the gearhead $(\mathrm{G})$ is limited to $8 \mathrm{Nm}$ (according to the manufacturer), so this value is adopted as referent value for the dimensioning of the planetary gearbox. The goal is to replace the currently used harmonic drive (HD) with the planetary gearbox (PG) while satisfying the prescribed kinematic and dynamic requests.

\subsection{Design requirements}

The requested number of revolutions for the upper arm remains the same: $n=15 \mathrm{rpm}$ and the torque at the input of the planetary gearbox equals: $T=8 \mathrm{Nm}$. The planetary gearbox also has to fulfil some additional requests:

- it has to have a higher load carrying capacity because it is intended for use in the design of robot joints which are considerably more loaded (such as shoulder joint, hip joint, knee joint, ankle joint etc),

- a significantly lower price in comparison with the existing harmonic drive,

- high efficiency in order to use motors with lower nominal power,

- it's dimensions have to be smaller or equal to those of the harmonic drive and

- the design solution has to be compact and its mass has to be as small as possible.

\section{SYNTHESIS OF THE PLANETARY GEARBOX}

In a planetary gearbox, at least one of the gears has a movable axis and this gear is called a planet gear. Planet gears are mounted on a moving element - the carrier. Gears with a fixed axis that coincide with the central axis of whole gearbox are called central gears: sun gears and ring gears.
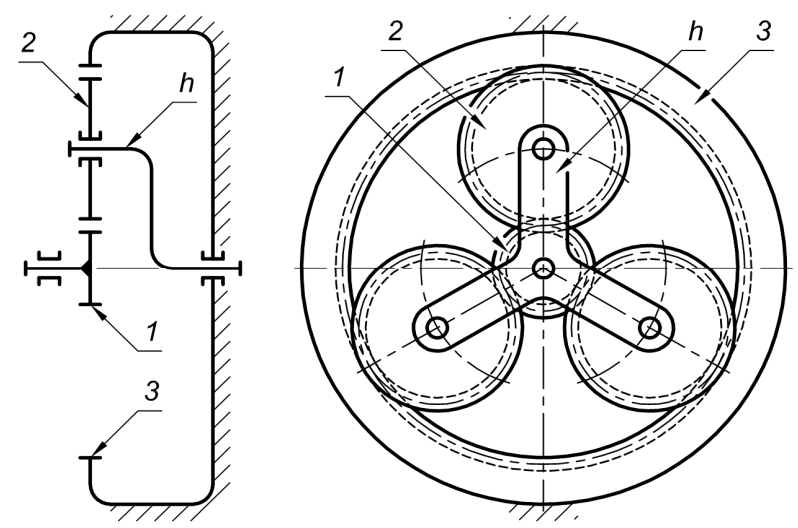

Figure 6. Planetary gearbox scheme

According to the design requests, a planetary gearbox with one degree of freedom was chosen (Fig. 6). Components of the selected planetary gearbox are: sun gear 1 , planet gear 2 , ring gear 3 (it is fixed i.e. $\omega_{3}=0$ ) and planet carrier $h$. Power is supplied by the sun gear and is taken by the planet carrier. This type of planetary gearbox has a high coefficient of efficiency for values 
of the transmission ratio from 3 to 9 (table 1.1 from [13]), it has a notably small mass and dimensions and it is simple to produce. Transmission ratio $i=5$ was adopted. The adopted gear type is a taper gear with a taper angle of 3 degrees. The material for all the gears is nitriding steel 14CrMoV6.9 (table 2.8.24 from [14]). By using nitriding, the surface durability of the gear tooth flanks is greatly increased. Nitriding is done at a lower temperature than carburizing, thus making it suitable for gears with modules value less than $1 \mathrm{~mm}$.

Data for calculation:

- input torque: $T=8 \mathrm{Nm}$

- output number of revolutions: $n=15 \mathrm{rpm}$

- transmission ratio: $i=5$

- gear material: 14CrMoV6.9

- tooth helix angle: $\beta=0^{\circ}$

- accuracy grade: IT5

- desired service life: $500 \mathrm{~h}$

\subsection{Calculation of the number of teeth}

For the selected transmission ratio $(i=5)$ and low circumferential velocities $(<1 \mathrm{~m} / \mathrm{s})$, the number of teeth adopted for the sun gear is (table 2.9.2 from [14]):

$$
z_{1}=20
$$

The number of teeth of the ring gear is calculated using the Willis equation (paragraph 1.5.2 from [13]):

$$
z_{3}=(i-1) \cdot z_{1}=(5-1) \cdot 20=80
$$

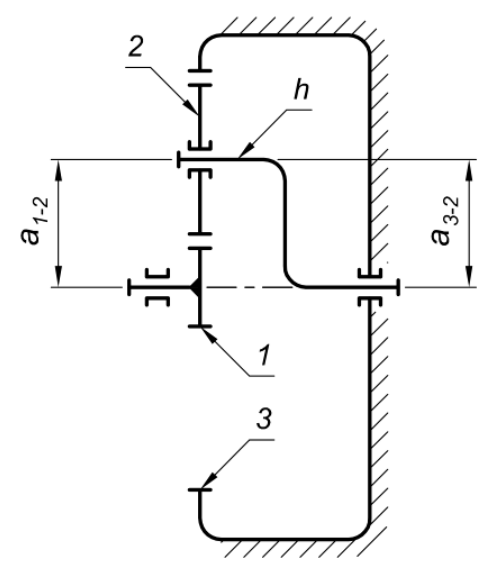

Figure 7. Coaxiality of the planetary gearbox shafts

The number of teeth of the planet gearbox is determined using the condition of coaxiality - equality of central distanced of the meshed gears i.e. concurrence of the central gear's axes and the whole planetary gearbox axis (Fig. 7), (table 1.4 from [13]):

$$
z_{2}=\frac{z_{3}-z_{1}}{2}=\frac{80-20}{2}=30
$$

\subsection{Calculation of the number of teeth}

The ring gear is fixed so its number of revolutions is $n_{3}=0$. According to the equation (paragraph 1.5.1.3 from [13]), the number of revolutions of the sun gear is:

$$
n_{1}=\left(1+i_{13}\right) \cdot n_{h}=(1+4) \cdot 15=75 \mathrm{rpm}
$$

where:

$i_{13}=\frac{z_{3}}{z_{1}}-$ transmission ratio of classical mechanical gear train (gears with fixed axes).

The number of revolutions of the planet gear, in respect to the carrier, is (paragraph 1.5.1.3 from [13]):

$$
\begin{aligned}
& n_{2}=(-1)^{m} \cdot i_{1} \cdot\left(n_{1}-n_{h}\right)= \\
& =(-1)^{1} \cdot 0,667 \cdot(75-15)=-40 \mathrm{rpm} .
\end{aligned}
$$

where:

$m$ - parameter that has value $1 / 0$ for outer/inner meshing of central gear and planet gear,

$i_{1}=\frac{z_{1}}{z_{2}}$ - partial transmission ratio and

$n_{h}$ - number of revolutions of the planet carrier.

\subsection{Calculation of the number of planet gears}

The number of planet gears in one plane is limited by the distance (f) between the addendum circles of meshed gears (Fig. 8). This geometric condition is also called the condition of contiguity and is used to calculate the number of planet gears (paragraph 1.6.1 from [13]):

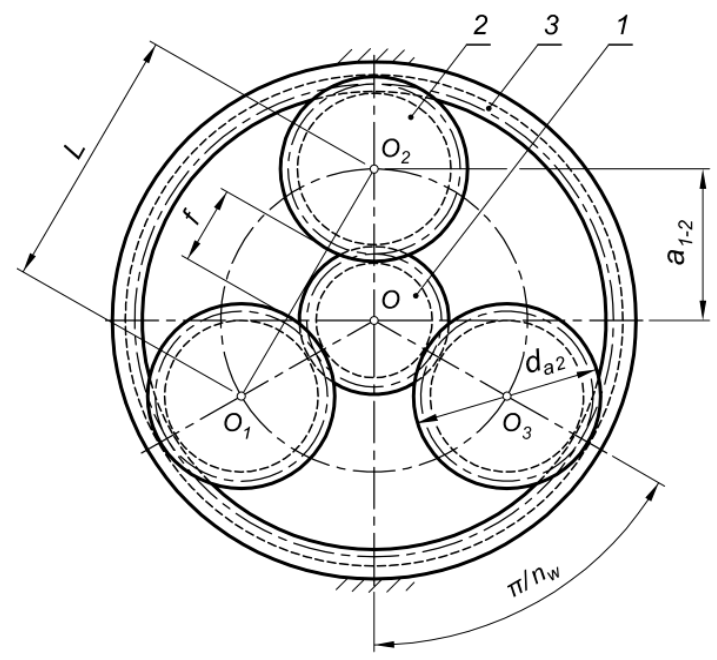

Figure 8. Displacement of the planet gears in the main plane of the planetary gearbox

$$
\begin{aligned}
& n_{w} \leq \frac{\pi}{\arcsin \left(\frac{z_{2}+2,5}{z_{1}+z_{2}}\right)}= \\
& =\frac{180}{\arcsin \left(\frac{30+2,5}{20+30}\right)}=4,44 .
\end{aligned}
$$

So, the number of planet gears can be 3 or 4 . A larger number of planet gears decreases overall the dimensions of the gearbox and increases its load carrying capacity. The final number of the satellites depends on the meshing condition which ensures simultaneous meshing of the planet gear and the central gears. Is expressed as (paragraph 1.6.2 from [13]): 


$$
C=\frac{z_{1}+z_{3}}{n_{w}}=\frac{20+80}{4}=25
$$

The condition is fulfilled because the sum of the number of teeth on the central gears is divisible with the number of satellites. Accordingly, the adopted number of planet gears is $n_{w}=4$.

\subsection{Calculation of the torques}

In order to calculate power flow through the planetary gearbox, it is necessary to calculate the forces on the gear tooth flanks and the forces on the planet carrier. Radial components of forces do not affect torque calculation so analysis is performed only with the tangential components.

Power flow in the planetary gearbox, and the forces and torques acting upon elements of the gear are presented on Fig. 9, where:

$r_{1}$ - sun gear radius,

$r_{2}$ - planet gear radius,

$r_{3}$ - ring gear radius,

$F_{21}, F_{12}$ - force with which the planet gear acts upon the sun gear and vice versa,

$F_{2 h}, F_{h 2}$ - force with which the planet gear acts upon the planet carrier and vice versa,

$F_{23}, F_{32}$ - force with which the planet gear acts upon the ring gear and vice versa.
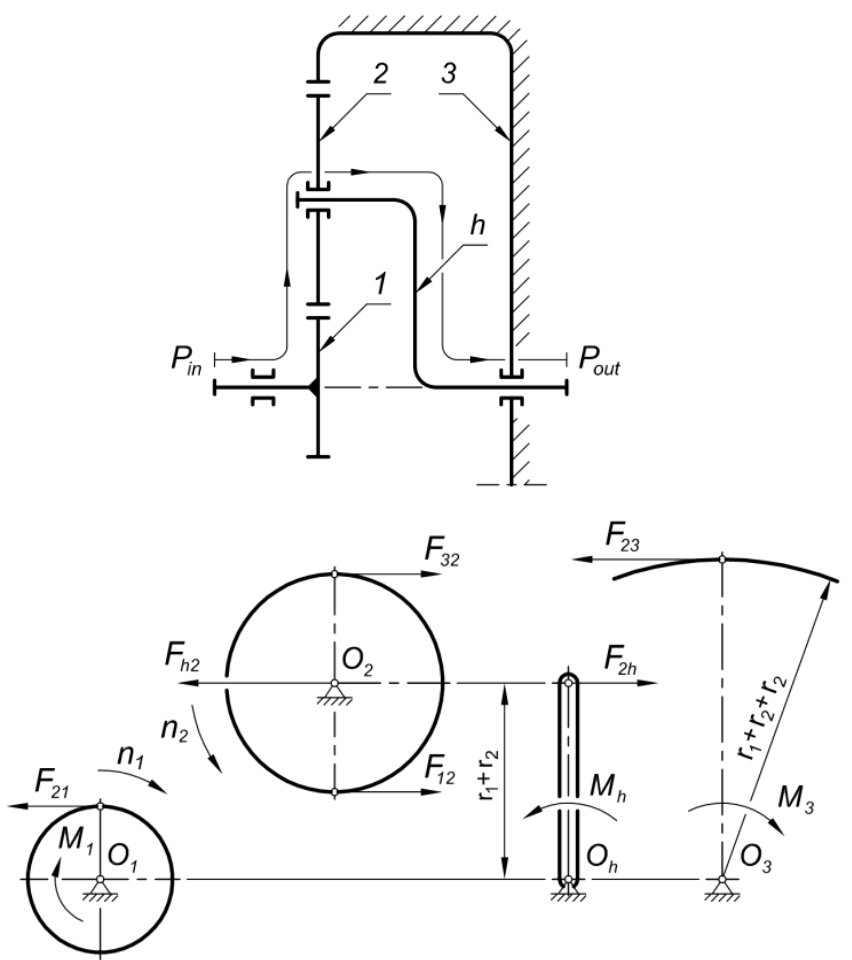

Figure 9. Power flow, forces and torques acting upon elements of the planetary gearbox

Torque on the ring gear is:

$$
\begin{aligned}
& M_{3}=n_{w} \cdot F_{23} \cdot r_{3}=-n_{w} \cdot F_{32} \cdot r_{3}=-n_{w} \cdot F_{12} \cdot r_{3} \\
& =n_{w} \cdot F_{21} \cdot r_{1} \cdot \frac{r_{3}}{r_{1}}=M_{1} \cdot i_{13}=8 \cdot 4=32 \mathrm{Nm} .
\end{aligned}
$$

Torque on the planet carrier is:

$$
\begin{aligned}
& M_{h}=2 \cdot n_{w} \cdot F_{21} \cdot\left(\frac{r_{3}-r_{1}}{2}\right)= \\
& =n_{w} \cdot F_{21} \cdot r_{1} \cdot\left(1+\frac{r_{3}}{r_{1}}\right)=M_{1} \cdot\left(1+i_{13}\right)= \\
& =8 \cdot(1+4)=40 \mathrm{Nm} .
\end{aligned}
$$

According to the equilibrium equation, the sum of all external torques acting upon the gear has to be equal to zero, so:

$$
M_{1}+M_{3}-M_{h}=8+32-40=0 \mathrm{Nm}
$$

\subsection{Calculation of the gear module and diameters}

Pinion diameter is calculated as (in this case sun gear is the smallest, so it is considered to be the pinion and is significant for the calculation) (equation (2.9.2) from [14]):

$$
\begin{aligned}
& d_{1}=850 \cdot \sqrt[3]{\frac{T_{1} \cdot K_{A}}{\psi_{b d}} \cdot \frac{S_{H \min }^{2}}{\sigma_{H \lim }^{2}} \cdot \frac{u+1}{u} \cdot \frac{K_{\gamma}}{n_{w}}}= \\
& =850 \cdot \sqrt[3]{\frac{8 \cdot 1,1}{0,8} \cdot \frac{1,2^{2}}{1270^{2}} \cdot \frac{1,5+1}{1,5} \cdot \frac{1,25}{4}}= \\
& =14,64 \mathrm{~mm} .
\end{aligned}
$$

where:

$T_{1}$ - torque on the sun gear,

$K_{A}$ - application factor (table 2.8.1 from [14]),

$\psi_{b d}$ - relation of width and reference diameter of the pinion, for symmetrical position of gear on the shaft and adopted material (table 2.9.1 from [14]),

$S_{H \text { min }}$ - minimal value of factor of safety coefficient for surface durability (paragraph 2.8.2 from [14]),

$\sigma_{H \text { lim }}$ - endurance limit for contact stress (table 2.8.24 from [14]),

$K_{\gamma}=1,25$ - load distribution factor for planet gears (paragraph 2.8.2.3.1.1 from [14]) and

$u=\frac{z_{2}}{z_{1}}-$ kinematic transmission ratio.

The adopted value for the pinion diameter is:

$$
d_{1}=15 \mathrm{~mm}
$$

With the value for the pinion diameter and the adopted number of the teeth of the pinion, module can be calculated as:

$$
m=\frac{d_{1}}{z_{1}}=\frac{15}{20}=0,75 \mathrm{~mm}
$$

The first larger standard value is adopted:

$$
m=0,8 \mathrm{~mm}
$$

With the adopted value of the module and the number of teeth on the other gears, the final values for gear diameters (sun gear, planet gear and ring gear) are: 


$$
\begin{aligned}
& d_{1}=m \cdot z_{1}=0,8 \cdot 20=16 \mathrm{~mm} \\
& d_{2}=m \cdot z_{2}=0,8 \cdot 30=24 \mathrm{~mm} \\
& d_{3}=m \cdot z_{3}=0,8 \cdot 80=64 \mathrm{~mm}
\end{aligned}
$$

\subsection{Calculation of the coefficient of efficiency}

Power loss in the planetary gearbox depends on the gear type, bearings, accuracy grade, loads, lubrication etc. and it represents one of the most important characteristics of the gearbox. For the presented planetary gearbox, efficiency is calculated in the following way (equation (7.9) from [15]):

$$
\eta=\eta_{h 1}^{3}=\frac{1-\eta_{13}^{h} \cdot i_{13}^{h}}{1-i_{13}^{h}}=\frac{1-0.98 \cdot(-4)}{1-(-4)}=0.97
$$

where:

$\eta_{13}^{h}=\eta_{12}^{h} \cdot \eta_{23}^{h}=0.99^{2}=0.98$ - efficiency of the gearbox with the planet carrier fixed,

$\eta_{12}^{h}$ - efficiency of gear pair 1-2,

$\eta_{23}^{h}$ - efficiency of gear pair 2-3 and

$i_{13}^{h}$ - transmission ratio with the planet carrier fixed.

\subsection{Gear strength calculation}

Gear strength calculation is done for each gear pair with respect to the endurance limit for contact stress and the bending endurance limit. The relation of critical stress and working stress is called the safety factor and its minimal values are (paragraph 2.8.2 from [14]):

$S_{H \text { min }}=1 \ldots 1.2$ - for contact stress and

$S_{F \min }=1.25 \ldots 2.5$ - for bending.

Safety factor for pitting (for the sun gear, planet gear and ring gear):

$$
S_{H}=1.16 \ldots 2.89>S_{H \text { min }}
$$

Safety factor for bending (for the sun gear, planet gear and ring gear):

$$
S_{F}=4.16 \ldots 4.38>S_{F \min }
$$

Considering the calculated values for the safety factors and the fact that the working regime is intermittent, it can be concluded that the gears are properly designed.

\section{DESIGN SOLUTION}

According to requirements and design limitations, a single-stage planetary gearbox with a transmission ratio of $i=5$ has been designed and its scheme is presented on Fig. 10. It has a driving sun gear (1), four planet gears (2) and a fixed ring gear (3). Gear diameters are: $d_{1}=16 \mathrm{~mm}, d_{2}=24 \mathrm{~mm}$ and $\mathrm{d} 3=64 \mathrm{~mm}$, and the numbers of teeth are: $z_{1}=20, z_{2}=30$ and $z_{3}=80$. The gear module is $0,8 \mathrm{~mm}$. The design solution is compact (the distance between planet gears is $\mathrm{f}=2.7 \mathrm{~mm}$ ), it has a small mass and overall dimen-sions (maximal diameter is $76 \mathrm{~mm}$ ).

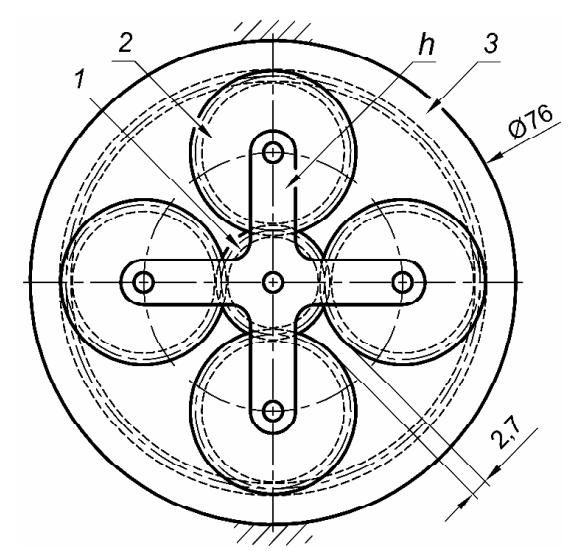

Figure 10. Scheme of the proposed planetary gearbox

The taper gears of the planetary gearbox have cylindrical outside diameter, cylindrical root and tapered flank. Radial forces which act upon the sun gear are self balanced so the sun gear is loaded only with the torsion torque. This means that a motor with smaller dimensions, whose shaft can sustain lesser values of radial and axial forces, can be applied.

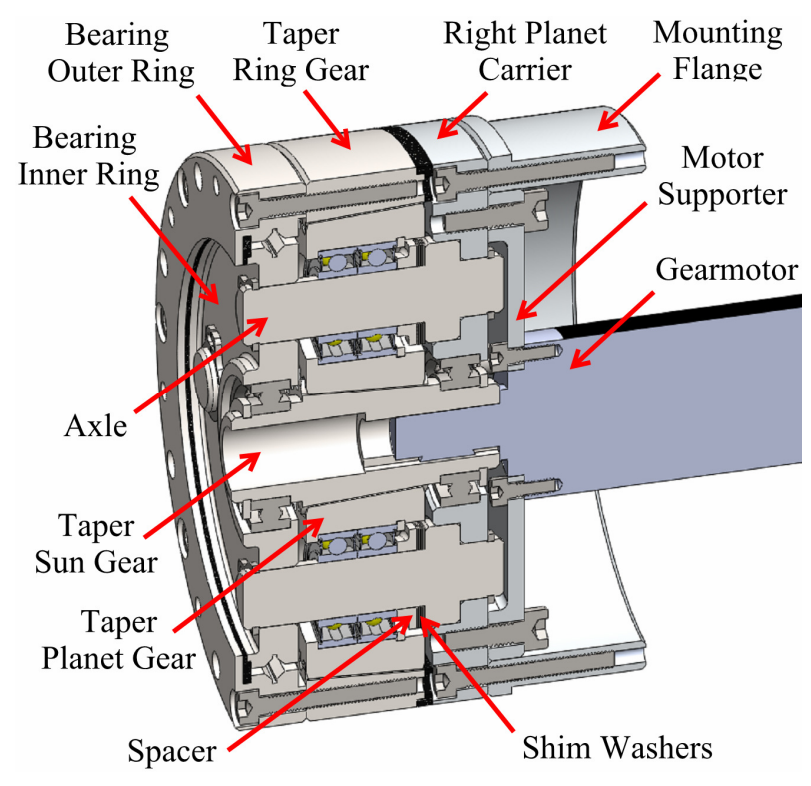

Figure 11. Planetary gearbox with taper gears - cross section

A cross section of the planetary gearbox with its main components is presented on Fig. 11. The ring gear is attached to the bearing output ring. The motor is attached to the right planet carrier via the motor support and is also grooved into the sun gear. The mounting flange is attached to the right planet carrier and is covered with a carbon shell. The left planet carrier has two parts (inner and outer ring) and is designed using radial bearing technology with four points of contact.

Torque goes from the gearmotor, over the sun gear and the planet gears to the planet carrier thus starting the rotation of the mounting flange. The gearmotor and the mounting flange rotate in the same direction.

Backlash is regulated through the axial repositioning of the planet gear. In order to decrease backlash, the planet gear is moved towards the sun gear and the ring 
gear, both of which are stationary. Axial displacement of the planet gear is realized by using the necessary number of shim washers (DIN 988) which are placed on the planet gear axle.

Because of its small dimensions, the presented design does not incorporate elements for equalizing uneven load distribution among the planet gears, so, it is very important to ensure high accuracy grade of the manufactured parts and elements as well as precise assembly.

Presented solution has a higher load capacity, low backlash, high efficiency and a significantly lower price in comparison with the harmonic drive - table 1.

Table 1. Comparison of the harmonic drive and designed planetary gearbox with taper gears

\begin{tabular}{|l|c|c|}
\hline & $\begin{array}{c}\text { Harmonic Drive } \\
\text { CPU-14A-100-M }\end{array}$ & $\begin{array}{c}\text { Planetary } \\
\text { Gearbox }\end{array}$ \\
\hline Torque $[\mathrm{Nm}]$ & $7,8 \ldots 11$ & 40 \\
\hline Transmission ratio & 100 & 5 \\
\hline Backlash [arcmin] & $<1$ & $<4$ (estimated) \\
\hline Efficiency [\%] & 65 & 97 \\
\hline Weight $[\mathrm{kg}]$ & 0.54 & 0.60 \\
\hline Dimension $[\mathrm{mm}]$ & $\varnothing 78 \times 32$ & $\varnothing 76 \times 34$ \\
\hline Price $[€]$ & 1200 & 240 \\
\hline
\end{tabular}

Load capacity is four times larger than that of the harmonic drive, the efficiency is higher and the price is five times lower (price of the new gearhead $(\mathrm{G})$ is included). Weight of the planetary gearbox is $10 \%$ larger while overall dimension are nearly the same. A significant advantage of the harmonic drive is the low backlash $(<1$ arcmin). Backlash of the planetary gearbox has to be determined on a real model, but it is estimated to be less than 4 arcmin [7]. The gear ratio of the planetary gear is 20 times smaller, so a new gearhead (G) has to be chosen (with a 20 times larger gear ratio) in order to maintain the kinematic-dynamic requirements (angular speed and torque on the upper arm). Nevertheless, gearheads with larger values of the gear ratio have a lower efficiency and a larger backlash. The first solution $(\mathrm{G}+\mathrm{HD})$ has a smaller backlash in comparison with the proposed solution $(\mathrm{G}+\mathrm{PG})$ while overall efficiency is better for the $(\mathrm{G}+\mathrm{PG})$ solution - it is $5 \%$ higher.

\section{CONCLUSION}

A typical mechanical transmission in humanoid robotics has to have a high load capacity, backlash as small as possible in order to maintain positioning and repeatability of the movement, high efficiency so smaller motors can be used, compact design, small overall dimensions and mass, and an acceptable production price.

The proposed solution of the planetary gearbox with taper gears has low backlash ( $<4$ arcmin), a high load capacity that is four times larger than that of the harmonic drive, higher efficiency and the price is five times lower. The weight of the planetary gearbox is $10 \%$ larger while overall dimension are nearly the same. A significant advantage of the harmonic drive is the low backlash (less than one angular minute) which is very important for positioning and repeatability of the move- ment. Said characteristics, together with the small mass, overall dimensions and low production price justify the application of the presented solution.

Minimization of the backlash in the planetary gearbox can be done by using helical gears and double helical gears. Higher contact ratio not only means smaller backlash, but higher load capacity of the gears, so it is obvious that application of helical gears or and double helical gears could improve the design. On the other hand, helical gears generate axial forces which are highly undesirable but can be eliminated with double helical gears or herringbone gears. The helix angle can be raised up to 45 degrees thus increasing the number of meshed teeth and the load capacity, and minimizing backlash which is one of the objects of further research.

Further research will also deal with the parametric optimization of the planetary gearboxes with spur gears, helical gears and double helical gears (a practical realization of these gearboxes is planned to reliably determine the different backlash values and general performance).

Real working conditions (uneven load distribution among the planet gears) usually cannot be properly modelled. So, it is imperative to investigate the stress state in the gear teeth using the finite element method (FEM analysis) as a part of further research.

\section{ACKNOWLEDGMENT}

This work was funded by the Ministry of education and science of the Republic of Serbia under contract III44008 and by Provincial secretariat for science and technological development under contract 114-4512116/2011. The authors are grateful to Dunkermotoren for support and motors donation.

\section{REFERENCES}

[1] Borovac, B., et al.: Humanoid robot Marko - An Assistant in Therapy for Children, in: Proceedings of the 10th International Symposium Research and Design for Industry, 11.12.2014., Belgrade, pp. 1-6.

[2] Savić, S., Raković et al.: Nonlinear Motion Control of Humanoid Robot Upper-Body for Manipulation Task, Facta Univer-sitatis: Automatic Control and Robotics, Vol. 13, No. 1, pp. 1-14, 2014.

[3] Catalog, Harmonic Drive AG, 2014.

[4] Kuzmanović, S. and Rackov, M.: Gearmotors with Low Backlash in Army Engineering, Military Technical Institute Belgrade, Vol. 47, No. 1, 2012. (in Serbian)

[5] Kuzmanović, S., Verě̌, M. and Rackov, M.: Product design as the key factor for development in mechanical engineering, in: Proceedings of the International Conference Mechanical Engineering in XXI Century, 25-16.11.2010., Niš, pp. 113-116.

[6] http://www.neugart.de

[7] http://www.ondrives.com

[8] http://www.sumitomodrive.com

[9] http://harmonicdrive.de

[10] Penčić, M., et al.: Development of the Planetary Gear for Humanoid Robots, in: Proceedings of the 
16. International Scientific Conference on Industrial Systems, 15-17.10.2014., Novi Sad, pp. 81-86.

[11] HMT Limited: Production technology, Tata McGraw-Hill Education, India, 2008.

[12] Radzevich, S.P: Gear cutting tools - fundamentals of design and computation, CRC Press, Florida, 2010.

[13] Tanasijević, S. and Vulić, A.: Mechanical gears planetary gears and variators, Faculty of Engineering, Kragujevac, 2006. (in Serbian)

[14] Nikolić, V.: Mechanical elements - theory, calculation and examples, Faculty of Engineering, Kragujevac, 2004. (in Serbian)

[15]Rosić B.: Planetary gears - internal cylindrical pairs, Faculty of Mechanical Engineering, Belgrade, 2003. (in Serbian)

\section{РАЗВОЈ БЕЗАЗОРНОГ ПЛАНЕТАРНОГ ПРЕНОСНИКА ЗА ХУМАНОИДНЕ РОБОТЕ}

\section{М. Пенчић, М. Чавић, Б. Боровац}

У раду је приказан безазорни планетарни преносник за хуманоидне роботе као замена за таласни преносник. На основу прегледа постојећих решења коаксијалних безазорних зупчастих преносника, изабран је концепт безазорног планетарног преносника ca благо конусним цилиндричним зупчаницима. Извршена је синтеза планетарног механизма за дате кинематичке захтеве и конструктивна ограничења. На основу добијених резултата дефинисана је структура и параметри неопходни за пројектовање зупчастог преносника. Предложено решење планетарног преносника је детаљно анализирано са различитих аспеката. Резултати анализе показују да предложено решење има лучни зазор $<4$ arcmin, 4 пута већу носивост и 5 пута нижу цену од тренутно доступних таласних преносника уз висок степен искоришћења 97\%. Димензије су приближно једнаке, док је маса планетарног преносника $10 \%$ већа у односу на постојећи таласни преносник. 